\title{
A Mirage of Welfare \\ How the Social Question in India Got Aborted
}

Jan Breman

\section{AN AMBIGUOUS START}

The struggle for national independence was waged to gain not only freedom from foreign rule but also redemption from poverty, which held the large majority of the population captive. The development task at hand was entrusted to the vanguard of the Congress movement, which had launched the fight for autonomy against colonial domination. The constitution of the new nation prescribed equality before the law of all citizens and democracy as the organizing principle of the political order. Universalizing suffrage was an act of considerable civil courage in a society marked by hard-core social inequality. The recognition of this heritage remained veiled. The hierarchical ranking in a superiority-inferiority bind was attributed to the divisive impact of colonial policies that created contrasts and conflicts where togetherness in harmony existed. Mutuality was highlighted in the postulate of a village community founded on a division of labor in which peasant, artisan and service castes cooperated in reciprocity. It was an image strongly contested by B. R. Ambedkar. This advocate of the discriminated rearguard argued that enfranchisement of the pariah underclass would not result in their emancipation if they were not simultaneously rehabilitated to a proportionate share of economic and social rights.

India came out of colonialism with the large majority of the population living in villages and working in agriculture. Land distribution was highly skewed and the All India Congress Committee had gone on record promising "land to the tiller." To the extent land reforms were carried out, they benefitted the already betteroff and not the majority of the peasants who belonged to land-poor and landless castes-cum-classes. The Gandhian model of small-scale village development was 
completely ignored. The pretense of a socialist blueprint to the future was foregrounded in political statements, but the bottom ranks of the peasantry, identified in official reports as Scheduled Castes and Scheduled Tribes, were often still tied in debt bondage to substantial landowners. The relationship, one of exploitation mixed with a veneer of patronage, which provided sustenance to the landless household, broke down when, in the late colonial period, capitalism gained prominence. ${ }^{1}$ Labor became increasingly casualized, but wages remained as low as before, and the erosion of patronage inherent to the former bondage was not compensated by state-supplied social benefits at old age, disability, or bouts of unemployment. Agricultural labor was excluded from the redistribution of the surplus land that became available. Population growth went on unabated, and bringing down the high pressure on the resource base was a must. Agriculture had to be released from a low-productivity workforce redundant to regular demand. A better life was awaiting the rural underclasses in the city, where they would find steady employment in the mills that were expected to absorb and skill a huge amount of labor from the countryside. The path lying ahead was meant to repeat the urbanization-industrialization trajectory that the Global North had passed through one century earlier and for which "development" became the catchword. It was a scenario that, in the wishful thinking of India's founding fathers, would ultimately result in the creation of a welfare regime as it already existed in the advanced economies.

In the late colonial period, a city-based class of factory labor had emerged. While miners and plantation coolies in the remote hinterland constituted a much larger industrial (although unorganized) workforce, factories manufacturing textiles had emerged in urban growth poles such as Mumbai and Kolkata. Mill hands made up a tiny fraction of the total working population, but their presence was supposed to signal what the future would look like. The vanguard of the industrial times to come became organized in trade unions, which lobbied for the introduction of labor rights in legislation aimed to safeguard conditions of employment, including social security benefits and protection against adversity. Infrastructural modernization required huge capital investments, which called for state participation in the planned restructuring of the economy. The regulation of employment upgraded the welfare of the workforce engaged in what became known as the public sector. In official parlance, "labor" was understood to signify industrial work. The "workers" were identified as male factory hands in the modern economy, and their numbers would rapidly increase. The vast majority of the working population still engaged in agriculture lagged behind in backwardness and remained, beyond the care of government, stuck in deep poverty. The rural population increased from 298.6 million in 1951 to 837.7 million in 2011, respectively 83 percent and 69 percent of the total population. In this interval, the percentage of owner-cultivators in the agrarian workforce dropped from 72 percent to 45 percent, while agricultural labor doubled from 28 percent to 55 percent. $^{2}$ Guided more by fear 
of a growing restiveness than by the urgent need to improve the appalling plight of the rural poor, the Congress government of Gujarat finally decided in 1972 to prescribe what landowners would have to pay to agricultural labor, but the legal minimum wage failed to become effective. Mahatma Gandhi had insisted that the main worker's income should satisfy the basic needs of his household and went on public record asking for a family wage that identified the male head of the household as the sole provider. Underlying his proposal was the idea that wives should not engage in waged work but should stay at home and take care of their husband and children. In spite of his strongly biased gender leanings, the yardstick of the nation's founding father was the right to a human subsistence that included a broad package of basic needs. His subsequent reduction of a fair wage to a living wage was based on the argument that a decent reward for waged labor had to be fixed in accordance with what the employer could and should afford. However, no enterprise or industry would be allowed to operate without adequate remuneration for the labor employed. ${ }^{3}$

\section{A TURN FOR THE BETTER?}

In the mid-1970s a slight improvement could be observed among the subaltern ranks in the rural locations of my local-level research in Gujarat. The widening scale of the labor market facilitated daily commuting to the nearby town by bus or bicycle or going off for longer periods as migrants for the duration of the dry season. The increasing connectivity would have strengthened the bargaining position of the landless and land-poor in the village if the influx of outsiders had not correspondingly gone up at the same time. More space opened up also because of government schemes targeted on the rural poor to consolidate the vote bank, which the Congress Party required to stay in power. What became known as positive discrimination gave access to jobs in the public sector for the somewhat educated among its downtrodden constituency. Although only a forward section of Scheduled Castes and Scheduled Tribes benefited from job reservation in the public economy, it encouraged parents to send their children to primary school, in the hope that their offspring would be able to escape from the bottom of the labor hierarchy in which the victims of lifelong illiteracy remained entrapped. In my fieldwork locales, I found that toward the end of the twentieth century, twothirds of the men and three-quarters of the women in the landless class were still illiterate, but among the age cohorts below thirty years, that proportion was much smaller. Another hopeful sign was the promotion of public health care. Primary centers were set up to cater to the low-income population in the surrounding villages with free professional help and medicine. However, the services on offer were of an inferior quality. Opening hours were irregular, while absence of competent personnel, adequate equipment, and cost-free medication added to the lack of efficiency. 
Government agencies were somewhat more successful in settling the landless households in new quarters, although without giving them title deeds to their homestead plots. A major drawback was that these colonies were built on wasteland at the village outskirts and were difficult to access in the monsoon. Their shelters on their employer's land before had been self-built mud huts with overhanging thatched roofs that almost reached the ground, scattered over the locality but close to where they worked. Being clustered in compact settlements must have strengthened togetherness and a shared communal identity as tribal castes. Hidden out of sight, these jerry-built colonies without basic utilities resembled urban slums. House construction and provision of electricity came, of course, at a price but the rural underclasses expected these amenities to be uncharged public goods. Their daily wages fell already short of what they had to spend on bare survival. In the countryside, human resource development and gratification of basic needs stagnated.

The necessity to canvass votes motivated Congress politics to initiate the first social protection schemes that would reduce the threat of extreme vulnerability. In 1991, the National Commission on Rural Labour pointed out in its report that with 2.5 percent of GNP, India's spending on social security was lower than almost anywhere else in the world. ${ }^{4}$ Moreover, that budget targeted only formally employed labor in the urban economy, one-tenth of the total workforce. Congress reckoned to make political capital out of the state pension for aged and disabled workers without adult children and without any means of their own. However, the beneficiaries turned out to be few and far between. In 1987 I came across an old woman in one of my villages of fieldwork who had once received the prescribed monthly payment of fifty rupees. She herself and everybody else saw it as an unexpected act of charity, a stroke of luck rather than a right to which she could lay claim in future. Nobody was able to tell her what to do and where to go to get her state pension.

Declaring the state of emergency in 1975, Indira Gandhi launched the Twenty Point Program to eradicate poverty and to improve the quality of life for the underclasses. The slogan Garibi Hatao (Get Rid of Poverty) made her a popular, even a venerated figure as Mataji among the masses down and out. The Bonded Labour System (Abolition) Act of 1976 decreed the end of captivity, which held workers attached in debt to their employers. The new ordinance was inspired more by the idea that bondage was an uneconomic way to utilize labor than that it degraded and oppressed the workforce exposed to it. The legal prohibition of debt bondage stemmed above all from government's desire to accelerate the pace of capitalism by doing away with an employment modality held to be a relic from a feudal past. Declaring illegal what remained widely practiced turned out to be as ineffective as it had been before. The prime minister unleashed an authoritarian regime, resorted to forced sterilization practiced on Muslims especially, but was amazingly unsuccessful in imposing a diktat, during her rule of emergency. 
Were there no initiatives from civil society to improve the condition of the lower castes, which are also the lower classes, left behind by politics and policies? Gujarat has a proud record of what used to be called constructive work by grassroots activists. The Gandhian movement made special efforts to bring the tribal communities into mainstream society, and the landless serfs were told that they were going to be redeemed from bondage and poverty. To uplift the rural proletariat, a welfare organization was founded in 1961, but the misery in which they lived remained unaddressed. The promised progress did not materialize because its high-caste leadership refused to confront exploitation and oppression headon. In the orthodox Gandhian mission, disputes on the terms and conditions of employment had to be solved by arbitration and compromise. Whenever relationships between farmers and laborers became tense and strikes or fights broke out, the social workers insisted on nonviolence and rushed to restore class "harmony," The Gandhian welfare agency that became part of the Congress machinery obfuscated rather than advanced the emancipation of the rural poor.

\section{Labour Circulation}

I used to trace the landless from my fieldwork localities wherever they went. Going off was due to the growing lack of demand for agricultural labor but was also inspired by a strong distaste among the younger age set to remain stuck in subordination to the local farmers. The problem land-poor and landless families face is a perpetual budget deficit. The dispossessed do not have the cash required for all kinds of expenses in the capitalist economy that has emerged. Credit expresses for the dispossessed an obligation to repay the provider of the "loan" with labor. The cash received demonstrates the supplicant's incapacity to meet basic needs without being forced to acquire part of the cost of maintenance and reproduction in advance and restricts the latitude to move around beyond restraint. Members from the land-poor and landless households are mobilized in a state of immobility. They leave home, to return only when the self-skilled and low-paid work under the open sky for which they are recruited comes to an end, many months later. When the subsistence deficit in their hamlets is at its most urgent because of lack of work and income, jobbers go around shelling out earnest money that commits their catch to depart to faraway work sites when the monsoon ends. The gangs of migrants cannot leave the destination to which they are brought until they have worked off the advance payment. Once the debt has been cleared, they should be free to leave, but their wages are held back until the end of the season. If they run away in between, they lose the net balance of their earnings. Sometimes migrants are still in arrears on departure if they have asked for a large amount in advance to cover the expense of life cycle events such as a wedding among their kinsmen or a family member's failing health, or to pay off an outstanding debt, which includes usurious interest on the loan provided. 
The rural distress continues to be ignored by the government. More than half of India's workforce is still reported to make their living somehow in agriculture, but that sector's share has steadily fallen to about one-sixth of GDP. Footloose hordes roam around in search of escape from lack of income at home. In the early twentieth century, barely 5 percent of the population was urban based, and that figure remained low throughout the colonial era. That proportion went haltingly up to 18 percent in 1961 and further increased to 28 percent in 2001. A drastic change in economic policy has subsequently accelerated urban growth. But the assumption that under the regime of neoliberalism, employment would surge ahead and raise urban life standards all around is misconceived. Both housing and jobs in cities lag far behind the accelerated intrusion of rural migrants desperate to establish a firm foothold in the urban economy.

\section{Waiting for a Bright Future}

In the mega-cities that have emerged during the last half century, slum dwellers outnumber the better-off inhabitants. While the classes mired in poverty try to hang on where they have squatted down, as close as possible to where the wellestablished citizens live, the latter experience their nearby presence as a nuisance. Driven out from their makeshift and unauthorized shelters, the unwanted inhabitants are dumped at the city's outskirts_-removed from sight but as a reserve army of labor, still sufficiently near at hand for occasional part-time and cheap usage. The spatial-cum-social divide is articulated by a change in policy to informality. The concept owes its origin to Keith Hart, who published in 1971 a pioneering paper on what he called the informal sector. ${ }^{5}$ The term referred to a motley crowd of unskilled, low-paid, and irregular labor at the low and inchoate end of the urban economy to be found in the erstwhile third world at large. The idea was that these newcomers would gradually qualify for steady and decently paid jobs. Getting more skilled and bargaining their way up, they were going to cross the boundaries that kept them apart from formal employment opportunities.

Until the late 1970s, Congress and its leadership remained wedded to a socialdemocratic pathway of sorts. Progressive taxation and stringent regulation of private enterprise paved the road to what should have ultimately culminated in a welfare state. Inequality did not wither away, but neither was there an escalation of conspicuous wealth at the top end. Captains of industry, both respected and suspected, were held on a short leash. The buildup of a public economy created some space for upward social mobility. In 1947 India had fewer than ten million industrial workers, of whom only a quarter were employed in modern factories. This tiny fraction of the workforce was regarded as spearheading the new economy. Industrial employment was the shape of a future in which employers, workers, and the state would synchronize their interests for the common good. The state took a leading role in the infrastructural layout, and heavy industries were established 
in the public sector for the production of capital goods. The system of steady and regulated employment introduced in these enterprises helped to give labor a new dignity and was held up as the standard for private business to emulate. These workers enjoyed proper jobs and were paid a time-rated wage. In addition to their protected terms of engagement, a wide range of social benefits became statutory, bargained for by the trade unions in which the industrial workers and public sector employees were organized. This vanguard remained small in size, was reluctant to share its privileges with the overwhelming majority of workers outside of their ranks, and developed traits of a labor aristocracy. Endowed with prerogatives, the gap in life standard with the main body of the workforce, which remained stuck in agriculture and in the informal economy, escalated. Toward the end of the 1980s, the government had lost control over its agenda of development and became subservient to "liberalization," as dictated by the Washington consensus. It was a setback sealed by the collapse of a second world order that had attempted to find an alternative path to the future than the one traversed by the advanced capitalist economies. With most other third world nations, India became incorporated in a regime of neoliberalism under Western hegemony, a setting in which institutions operating under the auspices of the Bretton Woods and World Trade Organization constituted the globalized directorate. The structural adjustment policies carried out were instrumental in dismantling the public economy and blatantly announced as a poverty reduction strategy, severely cut down expenditure on social sectors such as housing, health, and education for the working classes.

\section{INFORMALITY AS THE REMEDY}

Informality turned out to be not a waiting room but an end station for the swelling workforce locked up in it. Industrialization did occur, but much more slowly than anticipated, while more and more people were being pushed out of agriculture and the village. They were mainly accommodated in construction, transport, trade, and services, or floated between them. Together these sectors far outweigh labor absorption in industry, and, as a consequence, the economic policy has radically changed course. Spurred on by the financial agencies of transnational capital, formalization of employment was not any longer the trajectory to follow. Informalization was now considered to be the solution rather than the problem. The new policy suggested that casualization would generate more and better paid jobs. By a sleight of hand, irregular, insecure, and unprotected work was proclaimed to be in the best interest of labor. Closure of the mills in the formal economy toward the end of the twentieth century meant the overnight dismissal of a massive workforce that lost, together with their regulated jobs, all labor rights and social benefits. Trade unions faded away from the laboring landscape.

In a case study, I traced the workers sacked from their mill jobs to the bottom of the urban economy, where they engaged in cutthroat competition for the 
trifle chores on hand. ${ }^{6}$ It put an end to class-based solidarity. The victims did not have any other option than to fall back on their primordial loyalties for livelihood. In their search for casual work, they articulated their identity of gender, caste, and creed as the only form of social capital left to them. In 2002 a pogrom swept through Gujarat with horrendous ferocity. Hindu politics were blamed for the orgy of violence that targeted the Muslim minority in what was a politically managed and state-backed operation, but the changing fabric of the economy played a major role. Lumpenized elements were at liberty to hunt and kill non-Hindu targets in the streets, forsaking the bonds of fraternity they had shared in the mills. As a consequence to the riots, the religious minority was driven out of the neighborhoods in which they cohabited with their Hindu workmates. The communal separation has hardened and expresses the politics of apartheid dictated from above. Downward mobility was not the only fallout of informalization, but it also put in jeopardy a democratic fabric that is based on balancing the interests of all stakeholders in a spirit of proportional equivalence and social justice.

From the commanding heights one more myth percolated, maintaining that the absorptive capacity of the informal economy is infinite and pretending that newcomers are always welcome to join their swollen ranks. The premise stands corrected when one bothers to find out how these niches are watched over against uninvited intruders. The work at hand may go on day and night, but bouts of overemployment alternate with underemployment-nothing to do for days on end. A major cause for ceaseless mobility is due to the need to leave wife and children behind in the village for lack of earning capability, as well as living space. Having these dependents around would be an unbearable burden, both in terms of care and cash spent on their maintenance. Within a cycle of fifteen to twenty-five years, the harsh conditions of employment and shelter result in premature exhaustion. It means an end to their working lives, if this does not happen earlier, when they fall prey to lasting injuries or chronic illness often caused by occupational hazards. The story adds up to concluding that dislocation, labor circulation, and informality are each other's handmaiden.

Of India's workforce-at the end of 2017 , roughly half a billion in a population of nearly 1.4 billion-the overwhelming majority is stuck in the informal economy.7 Over half of the men and women in what has remained of the formal economy-a small slice estimated to hover around 10 percent of the economically active population-are also engaged on informal terms in a race to the bottom. With the upswing to neoliberal policies since 1991, labor market dualism further accelerated. In the urban economy, regular work is still the most common employment status, but in the rural economy, casual work dominates. Of the total workforce, less than half is wage dependent and more than half self-employed. ${ }^{8}$ Socalled own-account work indicates the lack of proper jobs and is often disguised waged labor of outsourced activity. Since supply of labor far exceeds demand, the income of the casualized workforce tends to remain stuck close to or below the 
poverty line. There can be little doubt that the drive toward informalization is in the end self-defeating. What is going to happen next? Once privatized, public space, agency, and institutions are difficult to restore. To generate solidarity rather than rank competition and individuated self-reliance is bound to be an uphill task. The public sector has shrunk and is manned by employees paid out of the country's treasury: army, police, and a corps of major and minor officials, secure in their waged prominence, and in their elevated roles safeguarding what the state is and does.

\section{A TALE OF INCLUSION}

Which policy interventions have provided relief to the laboring poor? The oldest one is the public distribution system (PDS). Having its origin in the famine of the 1940s, rationing was revived in the early 1960 s to cope with acute food shortage. PDS makes subsidized food and some nonfood items available through a network of licensed fair-price shops. After decades of weak implementation, better targeting has slowly made PDS more effective. Still, wrong inclusion (of the nonpoor) and exclusion (of large chunks of the laboring and non-laboring poor) continues to be a major problem. The ration card is not valid outside the place of residence, which means that circular migrants hailing from other states remain excluded. A high percentage of adults or minors in the population at large suffer from undernourishment (one out of five) and of children underweight (close to half). Households need to provide proof of their improvidence. To qualify not only for low-priced grain but for all relief schemes, they have to be registered as being stuck below the poverty line (BPL) and are issued an identity card as testimony of their vulnerability. To be put on the list is a favor granted or withheld at the discretion of upper-caste gatekeepers, all the way from the village to higher up in the machinery of governance. I was around when, in 2002, the order from above came to close the local register to new BPL claimants.

Public housing has for many years been provided under the Indira Awas scheme: one-room tenements with brick and plastered walls, an iron-sheet entrance door, a window, and a roof of durable material. The annual quota remained low, sparingly allotted and spread over a large number of colonies, to impress a landless constituency that the Congress government was actively promoting the welfare of the underprivileged. Public health facilities were introduced in the 1970s and 1980s to provide medical care to the poor. Whatever little access to professional and cost-free expertise was made available fell short of solving their health problems. The usual practice is to stick to self-medication, and if that brings no reprieve, the next step is to consult a quack for an injection. The changeover to privatization means that over four-fifths of health expenditure comes out of people's pockets. A national health insurance scheme was introduced in 2008 , limited to families officially recorded as poor. The scheme allowed for in-patient treatment in selected 
private or public hospitals, but it excluded coverage for many ailments and disabilities to which the laboring poor are prone.

Which measures have been taken to redeem the poor from the illiteracy in which I found them at the beginning of my local-level research more than half a century ago? Nowadays most children do go to school. It is a change for the better, to which the government contributes, with incentives such as a meal at noon, crèches for younger kids, and care for young mothers and infants by locally recruited and trained women. However, the village school has become the domain of the poor since the nonpoor send their offspring to town for private education at considerable cost. Public schools have become the domain of the working classes and are of inferior quality. At the end of their short educational track, children are able to confirm identity by writing their name instead of falling back on their thumbprint, but the teaching they have received is not enough to allow them to read even a simple form and fill it out with the required data. It means they remain cut off from all information and incentives that would connect them to mainstream society.

How to generate employment for the land-poor and landless classes in the rural economy? A time-hailed recipe has been to arrange for public works. Pressured by social activists, the Congress government launched in 2005 a scheme that offered paid work for one hundred days a year to self-selected rural households at the legal minimum wage rate on projects designed and executed by the village council. The policy makers retracted extending coverage also to the urban economy. The employment provided has to be productive in nature: land leveling, digging wells, building check dams, and improving access roads, further increasing the lead of those endowed with assets. The Mahatma Gandhi National Rural Employment Guarantee Act (in daily parlance abbreviated to narega) did not envisage upgrading the habitat of the rural proletariat with house construction or sanitation, let alone to arrange for care for the elderly, the disabled, and for all those unable to cope with their misery and in dire need of some support. The number of days worked are much lower than promised. Also, the clause stipulating that people who want to participate in the locally framed and managed projects should be paid the regulated wage on days no work is made available has remained ineffective. To do so would amount to an unemployment benefit, a largesse that is politically not condoned. Irrespective of these shortcomings or outright failure to achieve the targeted objectives-as, for instance, in Gujarat-the nuanced conclusion must be that narega has been much better handled in the southernmost states. In Kerala, in particular, where wages are above the legal minimum, the program has become a feat of female participation and assertion. But wherever pressure from below for participation remains absent, fraud and corruption are rampant: men and women listed as working on a project are simply not there; those who manage to become enlisted neither get the full wage nor do they receive it in time. An argument in favor of continuation and expansion of the scheme is demonstrated by the fierce 
disapproval with which local employers react to public works, because they appear to act as a lever on the going wage rate.

The plight of a workforce doomed to footloose circulation seems to defeat the idea that the global countryside has reached its maximum population and will begin to shrink after 2020.9 In a worst-case scenario, the countryside may remain the waiting room for a reserve army of labor. A return of social Darwinism could imply closing the cities off from a further influx of surplus people in the hinterland. Locked away in villages, it would be easier to keep them in check than on the urban front. Out of sight in their rural slums, their massive presence can be ignored, and the policy of abandonment would keep them separated from the better-off citizenry. The plausibility of such a "solution" is given impetus by a bourgeois mentality aggressively antagonistic to a drift into the city of growing contingents of landless and land-poor from their scattered backyards. ${ }^{10}$ They are seen as a dangerous class not so much because they are found to pose a threat to social and political stability, but because their polluting nearness is considered a health and safety hazard and a hindrance to civic morality.

\section{A STATE IN DENIAL}

The scale of public relief required to bridge the gap from improvidence to wellbeing has not been made available. Still, the pledge of successive political regimes is and remains the inclusion of all. How to realize this objective laid down in the constitution? The policy is summed up in the slogan that the poor should be helped to help themselves, even if this implies self-exploitation and a gross denial of their human quality. It is part of a neoliberal dogma that sets the government free from providing social security and protection. The drive toward self-employment, selfprovisioning and self-representation is to hold people accountable for their own work and welfare arrangements. This is the marvel of Soto's brand of capitalism and its glorified success in sinking down to levels earlier unheard-of. ${ }^{11}$ Has the magic of making the poor bankable, obliging them to stand security for each other when applying for petty loans, resulted in less improvidence? Attempts to set up to the rural landless in petty business have by and large failed, also in my fieldwork localities. ${ }^{12}$ The wages paid out to them at day's end are instantly spent on basic maintenance, food before anything else. None of it can be saved to cope with the adversities that are an ironclad feature of their deficient subsistence. Animators of micro-credit schemes tend to portray the underclass as undeserving poor, afflicted with ailments attributed to their own defects-steadfast refusal to save up, above all-rather than to bonds of un- or underemployment and inadequate income. Refusal to pay a living wage to the rural poor, even when profits higher up continue to accrue, is accompanied by an unflagging insistence on the privatization of property. Articulation of ownership rights has led to the depletion of common resources such as access to the village wastelands. It meant the loss of communally 
held benefits that used to contribute crucially to the coping strategies of the rural poor and to denial of the right acknowledged in the past to squat down on unoccupied space in village or city.

Established by the government in 2004 to take stock of the informal economy, the National Commission on Enterprises in the Unorganized Sector (NCEUS) recommended the promulgation of a "social floor" of labor rights and standards: a national minimum wage and its effective payment, decent conditions of work, and the provision of social security. It would mean cost-free insurance against failing health and other benefits for the non-laboring poor. Parliament mandated in late 2008 the Unorganized Workers' Social Security Act, which sought to bring a modicum of public relief for people unable to take care of their own subsistence. ${ }^{13}$ There is little doubt that the stony silence in the official circuit to this piece of legislation had much to do with the evidence produced that a very large portion of India's informal workforce is mired in deep poverty and that their deprivation went unabated in the first decade of the new century. This was unwelcome news for policy makers and politicians who indulged in the comfort of high-growth rates without bothering to find out at what cost. The NCEUS panel clarified its point of view that inclusion is condition sine qua non to progress for the masses lagging behind, an intrinsic feature of participatory involvement without which the development objective is bound to fail.

Is there no anxiety in the top echelons of society that the anguish and anger building up down below might spill over in outbursts of violence? A century ago, the notion of la classe dangereuse played a pivotal role in the willingness of vested interests in the Global North to accommodate the underclasses into mainstream society. While the haves in that part of the world decided to change tack and facilitate the inclusion of the haves-not and built up the welfare state, India's better-off classes appear not to be unduly bothered by the prospect of a social revolt. In contrast to the working poor in the advanced economies, who got organized in trade unions and political parties when the pace of industrialization and urbanization started to accelerate, the drive toward informalization means that the underprivileged masses are a fragmented assortment, unable to team up in collective action. The social question came up in the Global North to address the growing imbalance between labor and capital in the transition from an agrarian-rural to an industrial-urban way of life. The underlying trend toward equality in the fabric of society gave impetus to the demand for a proportional share in the distribution of economic gains. In India, the social question does not even arise in a neoliberal economy bent on favoring the well-to-do and shutting up the voices of the poor. Coming close in my fieldwork to where they live and how they make do, I have never failed to be impressed by their courage and resilience to oppose the ordeal imposed on them. However, their protest and resistance in a low-key and lowprofile capacity tends to be much understated in writings on collective action, in a sphere of domination and repression very difficult to resort to. 


\section{A COURSE OF EXCLUSION}

A drastic political reversal came in spring 2014 with the transfer of power from Congress to the Bajap Political Party (BJP) anxiously trying to canvass the Hinduized majority in its fold. The electoral outcome demonstrated the collapse of the Congress subterfuge and its credibility in trying to placate the underclasses while serving neoliberal interests. Popular anger in reaction to massive corruption implicating politicians and bureaucrats contributed to the defeat. Underlying what cascaded into a rout was the loss of support from underprivileged segmentsScheduled Castes, Scheduled Tribes, and Muslims-disillusioned by what had been promised but never delivered. In an ironic twist, many of the non-poor also deserted the party, which used to prioritize their well-being. The dissatisfaction of this middle- to higher-ranking segment stemmed from the proclaimed intent of Congress to spread welfare to the bottom classes. Catering to these underprivileged needs was met with strong disapproval by the better-off classes of citizens bent on remaining the exclusive beneficiaries of growth. Redistributive policies had to be pretended for reasons of political legitimacy and, if not practiced right away, then at least forecasted, in order to appease a deprived multitude that within a fabric of democracy could not be alienated. This ballot-box logic has fallen on deaf ears in a civilizational setting of stifling inequality. Bailing out the people stuck far below the poverty line is not an acceptable proposition higher up, even when that policy vow does not go beyond paying lip service to it. What has been the fallout of the new political equation?

As far as handling the social question is concerned, a definite change for the worse. Of course, this opinion is not shared by the Hindutva set of power-mongers. The former entitlement approach, never properly implemented, was replaced by a faked empowerment policy. Narendra Modi was elected prime minister with the promise that growth and development for all and sundry would be his agenda. His declared strategy is to go along with what big business wants: an infrastructural buildout at the public expense, lower taxation, and a free hand for corporate capital. This course of unrestrained capitalism, he insisted, would be in the best interest of labor, since it was going to result in a hundred million jobs. Neoliberalism never had a better advocate in India, and captains of finance and industry eagerly sponsored his campaign. From the onset, a frontal attack lined up to do away with whatever small gains labor had been able to make under Congress patronage in the preceding decades. The new budget drastically cut back on already toned down social sector expenditure-public health, housing, and education-as part of a reform meant to promote privatization in all these fields. Government expenditure on health care is 1.4 percent of GDP, lower than nearly everywhere else in the Global South. The meager budget set aside for public education makes India once more stuck at the world's rock bottom. The next step was to withdraw laws called archaic that secure and protect the dwindled contingent of workers employed on 
conditions of formality. In the Indian Labour Conference held end July 2015, Modi labeled such regulations as counterproductive to free enterprise.

Funding set aside for the public works program offering employment to rural households was slashed at lower levels of governance. The Food Security Act, valiantly fought for by civil rights activists, has been held in abeyance in states under BJP rule. As long as Congress was in charge, the policy makers were tardy to concretize the right to inclusion, and the promised welfare for the underprivileged did not materialize. Under the new regime, there is a brutal unwillingness to arrange for public relief that addresses the agony of the destitute underclass. The Antyodaya Anna scheme, which provided a monthly grain ration to the nonlaboring poor, was phased out. It shares this fate with other benefits now scrapped as wasteful expenditure. The state-funded pension allowances are being retooled into contributory and self-financed ones. To facilitate market accessibility for the poor, a Unique Cash Transfer scheme has been announced that aims at shoring up workers in the informal economy. Equipped with a biometric identity card, a clientele deprived of state-financed largesse is encouraged to open bank accounts in which they will deposit pension payments from savings they themselves are supposed to make. It could be the running up to a Universal Basic Income (UBI) scheme, which may be experimented with as a policy ploy for self-provisioning. The beneficiaries would be kept responsible for all expenditure made by taking away much-needed subsidies on food, shelter, health care, education, and social security. In a newspeak jargon, Narendra Modi tries to cover up the reality of massive destitution. Politics of promised (though not practiced) inclusion have made way for rigorous exclusion. At the end of 2016, the prime minister suddenly demonetized high-value banknotes with the pretension to squeeze out black money. The operation completely failed to achieve this stated objective but created havoc in the cash-based informal economy, and it led to large-scale dismissal of its casual workforce and an income crunch for many months for the affected households. The introduction of a Goods and Services Tax a half year later had a similar devastating impact. Both interventions were meant to formalize the flow of capital and subject all financial transactions to state taxation while keeping labor thoroughly informalized in their condition of underpaid off-andon employment.

What will be the fallout of the widening divide between haves and haves-not? India's constitution prescribes inclusion of all, irrespective of social identity and economic status. Politicians and policy makers of diverse ideological denominations have no option but to repeat the mantra that welfare for all remains their modus operandi. As one of the state makers, B. R. Ambedkar, popularly called Babasaheb, drew attention to the discrepancy between the doctrine of political equivalence and the brutal praxis of socioeconomic inequity. The paradox could, in his opinion, only be solved by giving the downtrodden segments access to the rights they are due as citizens. The declaration of universal suffrage and the legal 
imposition of the equality principle, Babasaheb argued, collided with an ingrained hierarchy that implied sustained subordination for the people at the bottom. Their status beyond the pale was reinforced by an extremely skewed distribution of the sources of existence. Mahatma Gandhi tackled the social question suggesting that the lower castes should remain under high-caste tutelage, a guardianship that would oblige the latter to raise the morality as well as standard of living of the former in a benign relationship of dependency and care. However, on the dark underside, dispossession went on unabated, resulting in a degree of poverty that spirals into pauperism, while on the shiny side, unbound consumerism whets the appetite of the better-off for ever more. In 2017, 1 percent of the Indian population owned 58 percent of the nation's wealth. ${ }^{14}$ The idea that the more and the less welloff should be balanced in reasonable proportion to each other was never a popular credo and has faded away over time. That Gandhian wisdom of caring for the least and the last is incompatible with a predatory capitalism that drives the winners to unbridled accumulation while leaving the losers behind in misery.

\section{FROM DEFIANCE TO ASSERTION}

Does it mean that emancipation of the laboring and non-laboring poor has become unstuck? That would be a premature conclusion. First and foremost because the analysis in the preceding pages has to be nuanced since it cannot be generalized for India at large. Gujarat, where I have conducted most of my empirical research and which is one of the fastest-growing states, is at or close to the national bottom as far as wage rates for the laboring poor is concerned, an achievement that corresponds with its laggard score on the human development index. In the second place, due to an amorphous climate of defiance rather than because of concerted and collective action, even in the localities of my recurring fieldwork in Gujarat, absolute poverty is less stark than when I first came around more than half a century ago. The deprivation experienced is, in many cases, a relative one, caused by the widening gap with the better-off classes for the majority of the landless and land-poor households. Finally, the critical balance drawn fails to do justice to the social churning from below throughout the country. In some states other than the one on which I have concentrated my recurrent investigations, the underclasses appear to have acquired some more room to manoeuver.

It is not so easy to nail down the regional variation that exists and the causes of diversity. There are zones, mainly in the southern parts of the subcontinent, with moderate economic growth but more social progress, the outcome of populist politics. The so-called BIMARU states (Bihar, Madhya Pradesh, Rajasthan, and Uttar Pradesh) together with Odisha are marked by the least momentum of socioeconomic progress. Then there is a middle rank to which Maharashtra, Gujarat, West Bengal, and Karnataka belong, where, despite high industrialization and 
urbanization, the pace of social change is rather mediocre, and hence inequality spilling over into exclusion is very high. These regional contrasts have to be further complicated in terms of a vast divide between top and bottom ranks. In that frame, an uneven ranking is noticeable among the various communal categories of the underprivileged. Dalit assertion is spreading and has gained strength in Punjab and the Gangetic belt of North India in recent decades, but already much earlier it had surged forward in Maharashtra, Andhra Pradesh, and Tamilnad. It took longer for tribal identity to get articulated, but running through central India, covering one fourth of the country's districts, the adivasis are up in arms, in protest against oppression and dispossession, if not the destruction of their resources and habitat by corporate business. Sections of what are called the Other Backward Castes (that is, not scheduled in the lower ranks of identification) equipped with some assets are upwardly mobile in the informal economy and have managed to get more political clout in many states. Among Muslims, the assertion of communal profiling is least visible, clearly to avoid the risk that its manifestation might arouse suspicion of falling prey to an anti-national mindset. ${ }^{15}$ The convoluted pattern explains the differentiation throughout the country, for instance, in wage levels, rates of literacy, as well as success (or not) in getting access to state-provided benefits. In all these struggles, whatever progress made is due not to benevolence granted from above but to claims tenaciously fought for from below. The reservation that needs to be expressed is that the prioritization of communal identities has so far not resulted in a joint action front militating for inclusion on a shared platform of common claims. Moreover, the individual or collective backlash from the higher echelons against the growing assertion from below is ferocious.

In order to upgrade conditions of work and life to a basic level of human decency and dignity three factors in particular have to be foregrounded as preconditional: the presence of social activism propelled from civil society, a clean and efficient government machinery committed to the implementation of pro-poor policies, and, finally, effective participation of the targeted beneficiaries in the struggle for welfare. Jointly, these considerations seem to have found better ground in South India. Hopeful also is an ongoing restructuring of the social order. An upsurge of a social consciousness can be detected among the lower castes-cum-classes spread over the subcontinent, manifest in their refusal to continue living in subordination. What used to be a hierarchical ranking in a relationship of proclaimed superiority versus imposed inferiority collapsed when neither the claim by the higher castes of preeminence nor professed acceptance by the lower castes of their subalternity remained the thrust of their interaction. In my perception, the lower ranks never internalized their submissiveness and refused to retreat in a culture of poverty. Entrapped in servitude in the past, they were obligated to a show of deference, but those days of a compelling need to acknowledge ritualized domination have gone. They do not any longer dwell in the shadow of the high and mighty but are settled 
in their own makeshift colonies in village or city. Living together has stimulated common cause. Ela Bhatt, the founding mother of the Self-Employed Women's Association, captured this notion of constituting a collectivity with her autobiography, We Are Poor but So Many. ${ }^{16}$ These words convey the habitus of the rankand-file membership that she mobilized to join her trade union for self-employed female street vendors, scavengers, cart pullers, home-based workers, and others, recruited from a gamut of Scheduled Castes, Other Backward Castes, Scheduled Tribes, and Muslims. Another recent step in the same direction is the initiative of labor activists and nongovernmental associations to formulate a charter for workers' rights in the informal economy and to get organized for representation along those lines.

The caste ranking has veered away from being spread over a vertical slope to stretching out on a horizontal plane in a frame of which inequality and not hierarchy is the most striking feature. The assertion to equivalence from down under is expressed in the claim to be included into mainstream society. But the steep inequality inherited from the past has, since 1980, further spiraled in a context of globalized capitalism. If the plunder going on does not end, and if capital is not brought under public control, the democratic fabric of politics is bound to collapse. Narendra Modi has gone on record declaring that his "Gujarat model of growth with development"- which amounted to a gross denial of the rule of law, civil liberties, social justice, ghettoization of the religious minority and not just the practice but also the principle of equality-has become the agenda for national policies. It is up to the country's citizenry at large to open the gates to inclusion. The denial to do so cannot but lapse into in a regime of naked authoritarianism, to further fracture, if not annihilate, what is left of public agency and multiclass representation. With the communalist adage that all people are unequal, but some are more unequal than others, the BJP supremo may be tempted to give this regime a more exclusionary slant. Narendra Modi was already an avid adept of a post-truth style of politics in Gujarat long before it became practiced wide and far. No doubt, the state has to be blamed for its failure to alleviate mass poverty spilling over in destitution, but the social activism fighting this remissness should not merely focus on the lapse of public governance. Beyond that, the owners and managers of capital have to be held accountable for the manner in which they treat or, increasingly, either misuse or disuse the country's massive labor force. In the globalized economy, capitalism as the hegemonic mode of production still gets away scotfree from contributing to human existence also for the down-and-out. When the social question was originally raised, labor directly confronted capital to seek a fair deal in the sharing of profit and cost. That spirit has to be brought back again in the struggle for emancipation, but not any longer at the national level only. Capital has come to operate more and more worldwide, and to engage with it at this transnational site of confrontation is going to be a major challenge for labor and its well-wishers. 


\section{NOTES}

1. Further elaborated in J. Breman, Capitalism, Inequality and Labour Bondage in India. (Cambridge: Cambridge University Press, 2019).

2. Government of India, Ministry of Agriculture, Agricultural Statistics at a Glance (2015), 15.

3. S. S. Gupta, Economic Philosophy of Mahatma Gandhi (New Delhi: Delhi Printers, 1994).

4. Government of India, Report of the National Committee on Rural Labour, overview, vol. 1 (Delhi, 1991).

5. Keith Hart, "Informal Income Opportunities and Urban Employment in Ghana," Paper delivered to a conference on urban unemployment in Africa. Institute of Development Studies, University of Sussex, 12-16 September 1971. Included in R. Jolly, E. de Kadt, H. Singer, and F. Wilson, Third World Employment: Problems and Strategy (Harmondsworth: Penguin, 1973), 66-70.

6. J. Breman, The Making and Unmaking of an Industrial Working Class: Sliding Down the Labour Hierarchy in Ahmedabad (New Delhi: Oxford University Press, 2004).

7. National Commission on Enterprises in the Unorganized Sector (NCEUS), The Challenge of Employment in India, vol. 1, main report (New Delhi, 2009). See also J. Breman, At Work in the Informal Economy of India: A Perspective from the Bottom Up (New Delhi: Oxford University Press, 2013).

8. T. S. Papola and K. P. Kannan, Towards an India Wage Report (ILO Asia-Pacific Working Paper Series, 2017).

9. M. Davis, Planet of Slums (New York: Verso, 2006; reprinted 2017).

10. J. Breman, On Pauperism in Present and Past (New Delhi: Oxford University Press, 2016).

11. H. de Soto, The Other Path: The Invisible Revolution in the Third World (New York: Harper and Row, 1989); and The Mystery of Capital: Why Capitalism Triumphs in the West and Fails Everywhere Else (London: Basic Books, 2000; reprinted 2003).

12. J. Breman, The Poverty Regime in Village India (New Delhi: Oxford University Press, 2007).

13. NCEUS, The Challenge of Employment in India, 152.

14. F. Alvaredo, L. Chancel, T. Piketty, E. Saez and G. Zucman, eds., World Inequality Report 2018 (World Inequality Web 2018).

15. Throughout South Asia, majoritarian politics are ferociously practiced, excluding religious minorities as hated outsiders in our midst. It is a denial of earlier statehood, which wanted to forefront secularism, as incorporated in the country's constitution, together with a culture encouraging tolerance and pluriformity. The Hindutva ideology raging in India has led to the deprivation of Muslims from citizenship rights and to their disenfranchisement in many states.

16. E. Bhatt, We Are Poor but So Many: The Story of Self-Employed Women in India (New York: Oxford University Press, 2006). 